\section{Intersections}

Canadian Journal of Music

Revue canadienne de musique
Intersections CANADIAN JOURAL OF MUSIC
REVUE CANADIENEE DE MUSIOUH

\title{
True Reflections on Barron's Reflections of Canada: “Canada 150: Music and Belonging”
}

\section{Ardelle Ries}

Volume 36, numéro 2, 2016

URI : https://id.erudit.org/iderudit/1051597ar

DOI : https://doi.org/10.7202/1051597ar

Aller au sommaire du numéro

\section{Éditeur(s)}

Canadian University Music Society / Société de musique des universités canadiennes

\section{ISSN}

1911-0146 (imprimé)

1918-512X (numérique)

Découvrir la revue

Citer cet article

Ries, A. (2016). True Reflections on Barron's Reflections of Canada: “Canada 150: Music and Belonging”. Intersections, 36(2), 47-55.

https://doi.org/10.7202/1051597ar
Résumé de l'article

Le professeur de musique canadien réputé qu'est John Barron (1939-2014) a commandé et édité l'ouvrage intitulé Reflections of Canada (RofC), réunissant en trois volumes 147 chants canadiens traditionnels arrangés entre 1985 et 1991 pour choeur a capella. Publié par les éditions Frederick Harris Music, RofC inclut des chants traditionnels empruntés aux traditions autochtones, française et anglaise, et a été considéré comme une ressource de qualité pour les enseignants en musique. À la fin des années 1990, RofC étant déclaré épuisé, les droits de publications sont retournés à l'éditeur, aux compositeurs des arrangements, et aux autres titulaires de droits d'auteurs. Afin de célébrer le cent-cinquantième anniversaire de la confédération canadienne, et à la demande générale, une deuxième édition en deux volumes de RofC a été lancée, cette fois conçue comme une recherche ethnographique. Nous examinerons les facteurs ayant influencé la genèse et la disparition de la première édition, pour ensuite analyser les processus et les défis ayant marqué la création d'une deuxième édition culturellement plus avertie, concrétisant ainsi une réflexion réaliste sur le Canada du vingt-et-unième siècle.
Copyright @ Canadian University Music Society / Société de musique des universités canadiennes, 2018
Ce document est protégé par la loi sur le droit d'auteur. L'utilisation des services d'Érudit (y compris la reproduction) est assujettie à sa politique d'utilisation que vous pouvez consulter en ligne.

https://apropos.erudit.org/fr/usagers/politique-dutilisation/ 


\section{TRUE REFLECTIONS ON BARRON'S REFLECTIONS OF CANADA: “CANADA 150: MUSIC AND BELONGING"}

26 May 2017

Ardelle Ries

Thank you for your attendance at this presentation, late on a Friday afternoon!1 It is a pleasure and privilege to have the opportunity to present at "Canada 150: Music and Belonging," to hear of the excellent work of Katie Tremblay-Beaton, Jeffrey van den Scott, and others. It is my hope that this session will serve to inform but, selfishly, to also bring added depth and insights to my research through questions and debate in twenty minutes' time.

My presentation will begin with the end in mind, as I will read the preface to the second edition of Reflections of Canada, recently published by Cypress Music in Vancouver. Much energy has been focused on this project for the last three, nearly four, years. As there are myriad sensitivities and vulnerabilities inherent in a project of this nature, it is hoped that these prefatory remarks that I have written will provide a context and holistic viewpoint.

In 1980, following fruitful discussions between John Barron, representatives from the Canadian Music Centre, music specialists from Middlesex County and four fine Canadian composers, the idea to create what could be called a musical reflection of Canada was born. The first edition of Reflections of Canada (RofC) was composed of a three-volume set featuring 147 a cappella arrangements of Canadian folk songs for two-, three- and four-part choirs. Nearly forty years later, after thorough consultation with a number of Canadian composers, ethnomusicologists, esteemed choral music educators from across the country, publishers, elders, Indigenous scholars, and the family of John Barron, it was decided that this second iteration of RofC would feature 50 of the best arrangements of selected Canadian folk songs.

This second edition of $R o f C$, first and foremost, must be looked upon as a beginning and not an end in itself. It is the first volume in a Cypress Music Singing the Circle series-a series devoted to the cultivation of singing culture in Canada-a singing culture for young and for old, for Canadians

1 This paper was presented at the MusCan conference in the spring of 2017. 
who have lived in this country since time began, for Canadians whose families arrived 400 years ago, and for new Canadians. The aim of the second edition of RofC within the Singing the Circle series is to provide a new, culturally sensitive, and informed lens in which to view and to study the songs of our ancestry and of our people.

21st-century Canada is a far different place than Canada of the 1980s. Our country has an immensely diverse ethnic population and, thanks to the heroic efforts of the Truth and Reconciliation Commission, progress has been made to assist all Canadians as we face a contentious colonial past.

The second edition of RofC sings the earliest stories of this land situated north of the 49th parallel with songs drawn from Indigenous-, French-, and English-speaking traditions. The Indigenous songs contained in the 2nd edition of RofC now include the names of the individuals who generously shared their songs in the early and mid-2oth century. Melodies of the Sioux and Ojibwe are now published as unison melodies without the trappings of a form steeped in the tradition of Western European classical music, as these exquisite melodies speak for themselves without the need of arrangement. With advice from Sioux, Ojibwe, and Inuktitut linguists from the University of Alberta and Nunavut Arctic College, relevant syllabics have been added, inappropriate poetic translations have been removed, and the songs have been given more suitable titles. In the case of the songs from Inuit traditions, the two-part choral arrangements have been preserved as Nancy Telfer's settings respectfully and tastefully portray the Inuit "duet" tradition of throat singing.

In many ways, the creation of this 2 nd edition is a labour of love and respect. First, for an enlightened, passionate, and influential music educator who was taken from Canada's music education landscape far too soon; second, for generations of singers and for the music of our land; finally, for the love of a welcoming, inclusive nation that is Canada-a nation that seeks to move into the future on the basis of deep understanding of our history and cultural traditions.

Isabelle Mills, University of Saskatchewan Professor Emeritus, conductor, and staunch advocate for Canadian music once wrote, "knowledge of the history of Canada is essential in the mosaic of Canadian folk song." It is my belief that an inversion of Mills' statement is most appropriate as we explore the 2nd edition of RofC and say: "Knowledge of the mosaic of Canadian folk song is essential in the knowledge of the history of Canada" (Mills, 1974).

With the second edition of RofC considered to be an arrival point, my goal this afternoon is to tell the story of the journey from the conception of the first edition through to the recent publication of the second edition. Alongside my story, this tale is also based on an extensive interview process that took place in 2015 with the family of John Barron just a little over a year after he succumbed to cancer at the age of seventy-five. Interviews were also conducted with composers/arrangers involved with Reflections first edition. 
For those of you who are not familiar with John Barron's work and enormous influence on choral music education in Canada, Barron was a Canadian choral conductor and music educator from London, Ontario. In 1975, John travelled to the city of Kecskemét, Hungary, with his wife, Lowell, and their three daughters to study the music education philosophy of renowned Hungarian composer, ethnomusicologist, educator, and linguist Zoltán Kodály.

John was in Hungary for just a little over one year and, after he immersed himself in Kodályian philosophy and to paraphrase Kodály's teachings, Barron wrote, "Folk songs constitute our 'musical mother tongue' and they should be part of every child's musical education" (Barron 1985, vi).

It was John's desire to create a body of Canadian folk song arrangements to model those that Kodály created between 1937 and 1942. Kodály's arrangements were intended to be sung by children's and adult choirs in the form of two-part (bicinia) and three-part (tricinia) treble arrangements and in settings for SATB mixed voices-in order to reach the Hungarian people who perhaps did not know the songs of their heritage.

Barron wrote, "It was generally agreed that there was very little Canadian part-song materials for use in our elementary and junior high schools, material that was relatively easy to sing yet of high artistic quality" (1985, vi).

In reference to the process in which songs were selected for the first edition, according to Canadian composer Nancy Telfer, one of the Reflections composer/arrangers,

John had quite a comprehensive knowledge of Canadian folk songs and he reviewed that and also researched libraries for more possibilities. He asked the arrangers for suggestions. John was keen from the start in including First Nations and Inuit songs. At this time, most of the Labrador songs were not well known at [all] outside of Labrador and he looked for more of those because it was such a rich area ... John received a huge amount of ongoing advice from the Kodaly group based in Middlesex County at that time ... As far as the other choices went (lyric, hearty, variety of structures/geographical location/text topics, etc.), John went through ... [a] balancing act ... to make the final choices. I can still hear the stress in his voice from conversations about this. ${ }^{2}$

The three volumes of the first edition of RofC were published between 1985 and 1987, followed in 1991 by Reflets $d u$ Canada, a volume consisting exclusively of French-Canadian folk song arrangements found in the three volumes of the first edition.

The first edition of the Reflections anthology was initially greeted with enthusiasm, with both English and French versions awarded Outstanding Choral Publication from the Association of Canadian Choral Conductors-now Choral Canada-in 1991. For nearly a decade, class sets were purchased for elementary, middle, and high schools; Reflections was adopted as a textbook for highly successful summer music education courses at a number of post-secondary institutions across Canada.

2 Nancy Telfer, electronic communication, 3 April 2016. 
The popularity of RofC was short-lived as, just a little over fifteen years after it was initially published, RofC was declared out of print by the Canadian publisher Frederick Harris Music. A number of factors played a role in the demise of RofC. First, Frederick Harris halted publication of choral music to focus on what has been labelled the "gold mine" of conservatory piano books. The creation of the Thames Valley School Board from the amalgamation of the Middlesex County, Oxford County, and Elgin County Boards of Education in 1988 coincided with drastic cutbacks to music education across the country. In true domino effect, these cutbacks prompted a dramatic reduction in music specialists, which, in turn, resulted in a general decline in standards for classroom and school music. Many teachers of the time began to consider the Reflections a cappella arrangements to be too difficult and outdated, with preference to enthusiastically explore and program world music. It was also at this time that American publishers began to dominate the publishing market, swallowing smaller Canadian music publishing houses.

As mentioned previously, in its prime, RofC was a required text for the University of Calgary summer Kodály course that flourished for nearly two decades. Lois Chosky, director of this successful Kodály summer program and UofC professor emerita wrote about the collection, "They have, in essence, created a Bicinia Canadiana. The authors have provided upper-level elementary school music classes, school choirs, and ear-training classes with material that is developmentally and pedagogically sound as well as artistically pleasing" (Barron 1985, v). She continued, "The songs themselves are a living history of this country ... No student who sings them can come away without a better appreciation of his or her heritage as a Canadian" (Barron 1986, v).

This last quotation is the perfect segue to the rationale for the creation of RofC second edition. It is without question that the first edition is narrow in focus; the treatment of Indigenous materials, from a twenty-first-century Truth and Reconciliation perspective, is questionable, limited, and culturally insensitive at best.

The question must be asked, Why bother to create a second edition of a resource that, to some, may be suspect in the first place?

Circumstances aligned in 2014 to create fertile ground for conception of Reflections second edition. John Barron's untimely passing in April 2014 coincided with the year that my university chamber choir was invited to perform at Podium, Choral Canada's national choral conference. The theme of the 2014 conference was "Bring Your Song." This theme resonated deeply with my choristers and with me and, in preparation for our performance at the conference, we closely examined the notion of musical identity, national identity, and singing identity. If we were to bring "our song" somewhere, what should it be? What are the songs of Albertans? Of Canadians? What are the songs that truly reflect ourselves or, using a term that my choristers and I may have coined, our song selves?

Through these discussions with the Augustana Choir undergraduates and with consideration to other work that I had done over the years with singers of all ages in relation to Canadian music, my perception was reinforced that 
many Canadians are unfamiliar with a common body of songs that could be labelled, in the broadest sense of the word, Canadian folk music.

These discussions combined with plans to mark the 15oth anniversary of confederate Canada prompted me to reconsider the a cappella arrangements.

With 2014 as the year of John Barron's passing, in tribute and also as a kind of experiment to determine if others would be as enthusiastic in this decades-old publication as my undergraduate choristers, I decided to go "old school" and, just as in the days of the UofC summer Kodály course, adopt one volume of Reflections of Canada as a textbook in the University of Alberta summer Kodály course- a two-week professional development course offered by the UofA Faculty of Education for graduate credit. Thanks to the UofA access copyright licence, multiple copies of volume 1 could be copied and accessible to the course participants. To my delight (if not surprise!), as the pre-service and in-service music teachers sang, memorized, and studied the arrangements that summer, there were repeated queries as to where class sets could be purchased. "They are out of print," was the repeated response.

The enthusiastic reception to Reflections by undergraduate and graduate students and in-service teachers, during the 2014-15 academic year, prompted me to continue to test the Reflections of Canada waters, but this time with elementary school children. The children I worked with in a large elementary school in my community appeared to have a limited knowledge of music that originated in Canada. I was again delighted to discover that children also enjoyed the songs and their stories and the singing! This enthusiastic multi-generational response, combined with encouragement from Kodály Society of Canada colleagues from across the country and a blessing from the family of John created perfect conditions for the birth of a project!

The birth of this idea, bolstered by encouragement of colleagues, was the easy part. As I began to analyze the first edition of RofC, it was clear that many more aspects prompted challenging questions:

- Comprising only Indigenous, English, and French songs, how could the second edition be an accurate "reflection" of twenty-firstcentury Canada?

- What of other significant ethnic groups?

- Were Indigenous melodies included in RofC drawn from ceremonial practice or shared freely with permission?

- Were Indigenous melodies and texts treated with cultural sensitivity?

These questions led to consultations with First Nations elders, school music specialists, choral conductors, ethnomusicologists, and composers to decide on the correct course of action for a second iteration of Reflections. From these discussions and debates, a number of interesting opinions and perspectives came to the fore. For example, it was suggested that only an online historic edition be created instead of print, because print music is no longer purchased and the Indigenous arrangements would be heavily criticized.

It was also suggested by an anonymous source that all songs attributed to Indigenous traditions be omitted entirely from the second edition: "Given 
where we are at present with the Reconciliation Commission and the healing and new learnings we are trying to effect, it seems totally inappropriate to include songs appropriated from Indigenous peoples, even those sung to a transcriber by a FN person. We don't know the circumstances under which those people singing their songs were existing at the time but we do know that non-Indigenous people collecting songs from Indigenous people brings with it a culture of power and appropriation."3

Nancy Telfer-the RofC composer/arranger, who also possesses a wealth of experience in the realm of multicultural music-had a strong reaction to these viewpoints: "As for the comment about people not buying print music, printed choral music continues to be a huge business in North America, Europe, and around the world ... millions of people [buy] print music." And in relation to the suggestion to create a historic, online edition, she wrote, "I cringe at that word 'historic' used for 'historic edition' which has the negative implication that this music is already dead. Folk music may change form but that is not the same as death."4

Telfer continues:

Re: cultural sensitivity, there may be some criticism about Indigenous material no matter what form the new edition takes so the form (print or online) may be irrelevant although I would expect a lot more criticism aimed at an online edition than at a print edition because of the bigger exposure online to large numbers of people who don't read music and aren't involved in institutional education and therefore don't understand that oral tradition is not the only way that culture continues to survive and thrive. But the most important thing to remember is that by far the greatest amount of criticism would be if the new edition does not include Indigenous material and, in my opinion, that criticism would be justified. 5

Additional advice from colleagues in post-secondary Aboriginal and Indigenous studies and a literature review on materials that address cultural appropriation and the treatment of Indigenous music in a choral context made me realize that to simply avoid the Indigenous music in the first edition could not be an option. There were too many collections of Canadian folk song published in the fifties, sixties, and seventies that include songs of the sailors, the lumberjacks, and the prairie homesteaders. A certain intuition, combined with enrolment in a course entitled "Building Capacity for Reconciliation," mandatory for all staff and faculty members in my University of Alberta Liberal Arts Faculty, prompted me to whole-heartedly embrace Nancy Telfer's perspective; however, with the inclusion of the Indigenous melodies, much had to be reconsidered in the manner in which these were treated for the second edition of RofC.

At a risk of redundancy, it was decided that $R o f C$ would:

3 Participant A, electronic communication, 5 May 2016.

4 Telfer (2016).

5 Ibid. 
- Take the form of a "best of" second edition prepared for 2017, with subsequent volumes published later to recognize the important musical traditions of other ethnic groups in Canada.

- Contain only 50 songs chosen from the original 147 to mark confederate Canada at 150.

- Include the Indigenous melodies but published as unison melodies.

- Recognize the names of those individuals from Indigenous communities who generously shared their songs! (In the first edition, these names, if they appear at all, are for the most part hidden within the acknowledgement or bibliography.)

- Remove inappropriate English poetic translations of the Indigenous songs and include more appropriate titles with syllabics from the relevant languages in question-Sioux, Ojibwe, and Inuktitut.

- Update first-edition phonetic pronunciations to reflect the most current information available in pronunciation of the Indigenous languages in question.

- Retain the two-part choral arrangement of the Inuit songs as the arrangements tastefully reflect the throat-singing duet tradition.

A team of music educators from coast to coast worked together to choose the 50 songs from the original 147 based on a number of criteria-questions:

- Which folk songs have excellent arrangements that already exist?

- What regions of the country does each song represent?

- Which songs provide valid historical background for students to learn about Canada?

- Is there a balanced representation of Indigenous, French, and English songs?

- Is there an equitable number of two-, three-, and four-part arrangements?

- What issues arise with the song due to texts that perhaps continue to promote some of the subtle and not so subtle misogynies that permeate old materials?

Cypress Music in Vancouver agreed to publish the fifty songs in two volumes, with volume 1 devoted to treble voices: unison, SA, and SSA; and volume 2 devoted to mixed voices: SAT, SAB, and SATB. This publication, the first of the aforementioned Cypress music series, Singing the Circle, is Kodály Society of Canada-endorsed and dedicated to the promotion of community and multi-generational singing! Release for this anthology is set for the 23rd International Kodály Symposium at the University of Alberta in August 2017.

Electronic resources with more comprehensive historical annotations, links to resource recordings and videos, and pedagogical suggestions will be prepared throughout autumn of 2017 and 2018 and available online through Cypress.

As a fitting and final statement, the words of the past-president of Choral Canada, Dr. Martha McCarthy ring true: 
The new edition of John Barron's Reflections of Canada will be welcomed for use by ... the members of Choral Canada, and by ... other singers throughout our nation, because it offers a unique means of celebrating Canadian diversity through song. Perhaps more importantly, however, is that this project will reach young people who do not identify as "singers": the materials in Reflections of Canada appeal to a broad range of interests and levels of musical experience. After all, folk song represents ordinary people, and is meant for everyone to enjoy ... The publication of this volume ... will provide an unparalleled resource for young people to learn about our identity as Canadians through holistic participation: because singing ... [is] very much like "walking in another person's shoes," young people will connect on a visceral level with the cultural expression of the First Nations people and of many ethnic groups who settled here. The manifestation of this project will provide a critical representation of Canadian history, language, and culture. Its experiential pedagogical approach will allow students and teachers across the country to actively encounter our history, celebrate our current diversity, and nurture mutual understanding for our future. (McCarthy 2016)

With thoughts of the end in mind, this project is just a beginning-a beginning for future publications, continued research, and further development of Reflections resource materials. It is my hope for those who elect to sing the songs from these volumes, that they will sing mindfully, equipped with knowledge of the stories and the histories.

\title{
REFERENCES
}

Barron, John, ed. 1985. Reflections of Canada. Vol. 1, Pine Tree Gently Sigh. Oakville, ON: Frederick Harris Music.

, ed. 1986. Reflections of Canada. Vol. 2, Les Raftsmen. Oakville, ON: Frederick Harris Music.

,ed. 1987. Reflections of Canada. Vol. 3, 'Twas in the Moon of Wintertime. Oakville, ON: Frederick Harris Music. ,ed. 1991. Reflets du Canada. Oakville, ON: Frederick Harris Music.

McCarthy, Marta. 2016. Choral Canada letter of support to Heritage Canada, 6 May.

Mills, Isabelle. 1974. "The Heart of the Folk Song." Journal for the Canadian Society of Traditional Music 2:29-34.

\begin{abstract}
Esteemed Canadian music educator John Barron (1939-2014) commissioned and edited Reflections of Canada (RofC) - a three-volume collection of 147 Canadian folk songs arranged for a cappella choirs between 1985 and 1991. Published by Frederick Harris Music, RofC contains folk songs derived from Indigenous, French, and English traditions and was considered to be a fine resource for music educators. In the late 1990s, RofC was declared out of print, with publishing rights returned to the editor, composers of the arrangements, and other copyright holders. To celebrate confederate Canada at 150 and brought back by popular demand, a two-volume second edition of RofC has
\end{abstract}


been created and will be released by Cypress Music in June 2017. Through narrative and ethnographic inquiry, the factors that influenced the genesis and subsequent demise of the first edition will be discussed, followed by an examination of the process and challenges encountered in the creation of a culturally sensitive second edition that embodies a realistic reflection of twenty-first-century Canada.

\section{RÉSUMÉ}

Le professeur de musique canadien réputé qu'est John Barron (1939-2014) a commandé et édité l'ouvrage intitulé Reflections of Canada (RofC), réunissant en trois volumes 147 chants canadiens traditionnels arrangés entre 1985 et 1991 pour chœur a capella. Publié par les éditions Frederick Harris Music, RofC inclut des chants traditionnels empruntés aux traditions autochtones, française et anglaise, et a été considéré comme une ressource de qualité pour les enseignants en musique. À la fin des années 1990, RofC étant déclaré épuisé, les droits de publications sont retournés à l'éditeur, aux compositeurs des arrangements, et aux autres titulaires de droits d'auteurs. Afin de célébrer le cent-cinquantième anniversaire de la confédération canadienne, et à la demande générale, une deuxième édition en deux volumes de RofC a été lancée, cette fois conçue comme une recherche ethnographique. Nous examinerons les facteurs ayant influencé la genèse et la disparition de la première édition, pour ensuite analyser les processus et les défis ayant marqué la création d'une deuxième édition culturellement plus avertie, concrétisant ainsi une réflexion réaliste sur le Canada du vingt-et-unième siècle.

\section{BIOGRAPHY}

An associate professor of music at the University of Alberta Augustana Faculty, Ardelle Ries a holds a passion for singing and song-based music education throughout all ages and stages of life. A strong musical and pedagogical foundation established at the Kodály Institute of the Liszt Ferenc Academy of Music provided Ardelle with the opportunity to be on faculty as an aural musicianship specialist in Hungary at the Kecskemét Kodály Conservatory and the International Kodály Seminar, and in Canada at Wilfrid Laurier University, the University of Calgary, and the UofA Faculty of Education. A staunch advocate for Canadian choral music, Ardelle has commissioned and premiered choral works from established and emerging Canadian composers and is the editor of the second edition of Reflections of Canada. Ardelle is an advisor to the Alberta Kodály Association and was the chair of the organizational committee for the 23rd International Kodály Symposium- “Singing the Circle." With over three decades of dedicated service to music education in Alberta, Ardelle is grateful to have been recognized as the 2013 recipient of Choir Alberta's Richard S. Eaton Award and the 2017 AKA Teacher Recognition Award. 